ISSN 1810-3030 (Print) 2408-8684 (Online)

Journal of Bangladesh Agricultural University

Journal home page: http://baures.bau.edu.bd/jbau, www.banglajol.info/index.php/JBAU

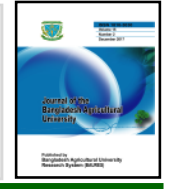

\title{
Domestication of red fin mahseer (Tor tor) with supplementary feeds in captive condition in Bangladesh
}

\author{
Muhammad Shalah Uddin Kabir ${ }^{1}$, Farzana Arefin ${ }^{2}$, Mohammad Matiur Rahman ${ }^{2},{ }$ Md. Rafiqul \\ Islam Sarder ${ }^{2}$ and Md. Fazlul Awal Mollah ${ }^{2}$ \\ ${ }^{1}$ Department of Fisheries, Bangladesh \\ ${ }^{2}$ Department of Fisheries Biology and Genetics, Bangladesh Agricultural University, Mymensingh-2202, Bangladesh
}

\begin{tabular}{|c|c|}
\hline ARTICLE INFO оPEN ${ }^{\text {Access }}$ & act \\
\hline $\begin{array}{l}\text { 9 August } 2018 \\
3 \text { December } 2018 \\
1 \text { December } 2018\end{array}$ & \multirow{3}{*}{$\begin{array}{l}\text { Effects of supplementary feeds on growth, survival, and production of red fin mahseer, Tor tor (Hamilton) } \\
\text { was assessed in captive condition under a monoculture system. Experiments were conducted for a period } \\
\text { of } 12 \text { months where two feeds varying in protein contents were used in treatments. One laboratory } \\
\text { formulated feed with } 36.67 \% \text { protein and a commercial feed with } 28 \% \text { protein were characterized as } \\
\text { treatment- } 1 \text { (T1) and treatment- } 2 \text { (T2), respectively. At the same time water quality parameters were } \\
\text { measured. The net increment in weight after } 12 \text { months was } 671.60 \mathrm{~g} \text { and } 509.80 \mathrm{~g} \text { in T1 and T2 } \\
\text { respectively. The feed conversion ratio (FCR) was } 4.72 \text { and } 5.26 \text {, and the specific growth rate (SGR) was } \\
1.39 \text { and } 0.10 \% \text { day }{ }^{-1} \text { in T1 and T2 respectively. In both treatments } 100 \% \text { fish were survived and provided } \\
\text { the net production (kg/ha) } 2807.06 \text { and } 2557.78 \text { in T1 and T2, respectively. The water quality parameters } \\
\text { were within the suitable range for fish culture. Between the feeds evaluated, feed with } 36.67 \% \text { protein } \\
\text { (T1) proved best result considering the growth and production performance of the fish. Overall growth } \\
\text { performance of } T \text {. tor was satisfactory; however, further research is needed. }\end{array}$} \\
\hline $\begin{array}{l}\text { otein; Growth } \\
\text { ce; Production, } \\
\text { ntary feed; T. tor }\end{array}$ & \\
\hline & \\
\hline
\end{tabular}

Copyright:

(c) (i)

(O2018 by authors and BAURES. This work is licensed under the Creative Commons Attribution International License (CC By 4.0).

\section{Introduction}

Among the fishes of family Cyprinidae, red fin mahseer T. tor is one of the most attractive fish of Bangladesh. It has high demand as table fish and lure for anglers as a game fish and is potential contender for aquaculture (Haque et al. 1995; Ingram et al. 2005, Ogale, 2002). Due to attractive color, it has high potential as ornamental fish in the aquarium fish industry $(\mathrm{Ng}$, 2004). In the past, T. tor was reported to be available in the hilly streams of Sylhet, Mymensingh, Netrokona, Dinajpur, and Kaptai reservoir of Chittagong Hill tracts in Bangladesh (Rahman, 1989). But in last couple of years, it is very rarely found only in the River Someshwari of Netrakona District (DoF, 2016). Because of various natural causes and manmade activities, the water flow of Someshwari has been reducing abruptly resulting loss of habitat of mahseer. Besides, the river is being used for livelihood of poor and ultra-poor people which is also responsible for degrading the habitat. People especially women, even children go to the river to collect coal particle and sand for their livelihood. Illegal gears are also used in the Someshwari for fishing. Moreover, unscientific coal mining in the upstream of the Someshwari at Meghalaya, India has provoked the problem incorporation with acid mine drainage (Mallik et al. 2015). Consequently, T. tor has been ranked as critically endangered in Bangladesh (IUCN, 2015).
T. tor is the symbol of aristocracy but did not get due attention from any corner of stockholders for its conservation. As in-situ conservation is practically impossible in the existing habitat, ex-situ conservation through domestication in captivity is a must to protect $T$. tor from extinction. Domestication of mahseer in captivity will also help to determine its culture potential. Over the last few decades, though some research on growth parameter and nutritional requirement of other species of Tor (Bista et al. 2002; Chatta et al. 2015a, 2015b and 2015c; Islam et al. 2002; Islam and Tanaka, 2004; Joshi et al. 1989; Misieng et al. 2011; Rahman et al. 2005; Rahman et al. 2007, Sawhney and Gandotra, 2010) have been conducted, very little information (Akram and Swapna, 2014; Lone and Lone, 2014) on $T$. tor have come to the light. Therefore, the present study was aimed to domesticate $T$. tor in captivity and to find out the appropriate supplementary feed as well as protein requirement for this species.

\section{Materials and Methods}

\section{Experimental Design}

The present experiment was conducted in earthen ponds under natural conditions for 1 year from 1 August, 2015 at the Faculty of Fisheries, Bangladesh Agricultural University (BAU), Mymensingh, Bangladesh. The experiment was conducted under two treatments without any replication. Two feeds with different proximate composition, particularly in the crude protein content were used. Formulated pelleted feed containing $36.67 \%$ 
crude protein was used in treatment-1 (T1) and a commercial pelleted grower feed (Mega feed) with $28 \%$ crude protein was used in treatment-2 (T2) and both the feeds were sinking in nature.

\section{Feed Formulation and Preparation}

The commercial feed was purchased from Spectra-Hexa Feeds Ltd., Bangladesh and the other feed was formulated by Pearson's square method and prepared at Bangladesh Fisheries Research Institute, Mymensingh. Feed was prepared by using locally available ingredients where water was added for proper mixing and the dough was extruded in an electric pelletizer. Pellet was dried by sun light. Vitamin-E (Vitax-ES, Eon Pharmaceuticals Ltd.) at the rate of $1 \mathrm{~g} \mathrm{~kg}^{-1}$ feed was added. Proximate composition of the experimental diets was determined following AOAC (1984) in the Fish Nutrition Laboratory at BAU, Mymensingh. Formulation and proximate composition of the experimental diets are shown in Table 1.

Table 1. Formulation and composition of the experimental feeds

\begin{tabular}{lcc}
\hline Feed Ingredients & \multicolumn{2}{c}{ Composition (\%) } \\
\hline & T1 & T2 \\
\hline & & $\begin{array}{c}\text { Commercial } \\
\text { feed (Mega } \\
\text { feed) }\end{array}$ \\
Fish meal & 35 & \\
Soybean meal(ACI) & 18.53 & \\
Mustard oil cake & 18.53 & \\
Rice bran & 10.47 & \\
M\&B meal & 10.47 & \\
Binder (molasses) & 3 & \\
Megabind & 2 & \\
vitamin-mineral premix (Vitatech, & 2 & \\
Aqua Tech Multipurpose & & \\
Hatchery Ltd.) & & \\
& Proximate composition & \\
Crude protein (\%) & (\% moisture basis) & \\
Crude lipid (\%) & 36.67 & 28 \\
Crude fibre(\%) & 9.80 & 8.08 \\
Moisture (\%) & 4.80 & 5.20 \\
Ash (\%) & 12.72 & 12.27 \\
Carbohydrate (\%) & 10.48 & 15.53 \\
\hline
\end{tabular}

\section{Pond Preparation, Stocking of Fish and Husbandry}

Two rectangular earthen ponds each of 4.0 decimal with an average depth of $1.5 \mathrm{~m}$ and having a routine water supply, inlet and outlet facilitates were used for stocking. Ponds were sun-dried for better mineralization, escape of toxic gases and to make free from aquatic weeds, harmful aquatic insects, predatory and weed fishes. Ponds were treated with lime at the rate of $1 \mathrm{~kg} /$ decimal and then filled with water. After seven days urea and triple super phosphate (TSP) were applied at the rate of $200 \mathrm{~g}$ and $100 \mathrm{~g} /$ decimal, respectively. T. tor was collected from the fish traders of Durgapur Upazila of Netrokona District who earlier collected those from the River Someshwari (Fig. 1). The stocking was done in ponds at the rate of six fish per decimal and reared for twelve months. Since the test species is critically endangered, and collection of fry is nearly impossible, large sized fish (size varying: 1179-1253 g) was used for the experiment. Fish were fed two times daily at $0900 \mathrm{~h}$ and $1700 \mathrm{~h}$ at the rate of 1.5 to $2 \%$ of body weight in both the treatments and the amount of feed was adjusted monthly based on body weight.

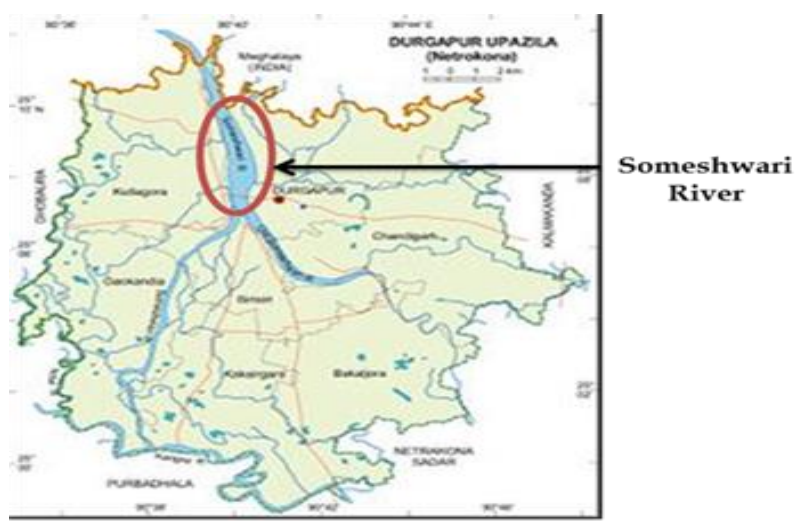

Fig. 1. Collection site (the River Someshwari) of T. tor in Durgapur Upazila, Netrakona

\section{Sampling of Fish}

Ten fish from each treatment were sampled randomly at each month, weighed individually and released back. At the end of experiment, all the fish were captured from both the treatments and determined their survivability.

\section{Water Quality Parameters}

Water quality parameters (water temperature, $\mathrm{pH}$ and dissolved oxygen) were recorded for a year at 9.00am and $2.00 \mathrm{pm}$ in each sampling date. Temperature was measured by Celsius thermometer; whereas dissolved oxygen (DO) and $\mathrm{pH}$ were recorded by Hanna DO meter (Model-HI 9146, Romania) and Milwaukee $\mathrm{pH}$ meter (Model- $\left.\mathrm{P}^{\mathrm{H}} 55 / \mathrm{P}^{\mathrm{H}} 56, \mathrm{USA}\right)$, respectively.

\section{Estimation of Growth and Survival}

For estimating the growth of fish, ten fish from each treatment were sampled monthly. Growth was studied regarding weight gain (g), weight gain (\%) and SGR. Weight gain was figured just by deducting the mean initial weight values from that of the final. Weight gain (\%) and FCR were estimated following Sawhney and Gandotra (2010) as follows:

$\%$ weight gain $=$

Mean final fish weight - Mean initial fish weight Mean initial fish weight

Food conversion ratio $(\mathrm{FCR})=\frac{\text { Feed fed }}{\text { Live weight gain }}$

SGR was computed after Brown (1957) as follows:

$\operatorname{SGR}(\% /$ day $)=\frac{\ln \mathrm{w}_{2}-\ln \mathrm{w}_{1}}{\mathrm{~T}_{2}-\mathrm{T}_{1}} \times 100$

where, $\mathrm{W}_{1}$ = initial live body weight $(\mathrm{g})$ at time $\mathrm{T}_{1}$ (day) and $\mathrm{W}_{2}=$ final live body weight $(\mathrm{g})$ at time $\mathrm{T}_{2}$ (day). 
At the end of the experiment, the survived fish were counted and weighed individually and the data were utilized for consequent analyses. Survival rates were estimated on the premise by counting the number of fish harvested (no. of fish harvested/no. stocked X 100). Production of fish was calculated by multiplying the average final weight of fish by the aggregate number and was expressed as $\mathrm{kg} / \mathrm{ha}$.

\section{Data Analysis}

Data were analyzed by the computer software MS Excel version 2007 as descriptive values such as mean and percentage. Data on growth was analyzed by computer software SPSS version 20.0 (Statistical Package for Social Science) using student's t-test at $5 \%$ level of significance.

\section{Results}

\section{Growth}

Results of different growth and production parameters are shown in Table 2 and Fig. 2. Mean weight gain in $\mathrm{T}_{1}$ and $\mathrm{T}_{2}$ were $671.60 \mathrm{~g}$ and $509.80 \mathrm{~g}$, respectively. Higher growth in terms of weight gain (g) was observed in $T_{1}$ compared to $T_{2}$. Though the weight gain of fishes in $T_{1}$ was apparently higher than that of $T_{2}$ but there was no significant difference $(p<0.05)$ between the treatments. The percent weight gain was also obtained higher in $T_{1}$ compared to $\mathrm{T}_{2}$. In both the treatments the survival rate was found $100 \%$ as the fish were larger in size. Both FCR and SGR were found better in $T_{1}$ than $T_{2}$.

\section{Water Quality Parameters}

The data of various physico-chemical parameters (mean values) of water of two experimental ponds are presented in Table 3. The minimum temperature in both the ponds was almost similar and found to be $22.0^{\circ} \mathrm{C}$ in January and the maximum of $32.6^{\circ} \mathrm{C}$ in April. The maximum value of dissolved oxygen $\left(7.2 \mathrm{mg} \mathrm{l}^{-1}\right)$ was recorded in October and the minimum $\left(4.8 \mathrm{mg} \mathrm{l}^{-1}\right)$ in February. The $\mathrm{pH}$ values of the two experimental ponds were also always found to be more or less in the optimum level. In both the treatments, the maximum $\mathrm{pH}$ 8.5 was recorded in July and the minimum $\mathrm{pH} 6.5$ in June.

Table 2. Growth, survival, and production of $T$. tor during the study period

\begin{tabular}{|c|c|c|c|c|c|c|c|}
\hline \multirow[t]{2}{*}{ Treatment } & \multirow{2}{*}{$\begin{array}{l}\text { Mean weight } \\
\text { gain }(\mathrm{g})\end{array}$} & \multirow{2}{*}{$\begin{array}{c}\text { Percent } \\
\text { Weight gain }\end{array}$} & \multicolumn{2}{|c|}{ Production $(\mathrm{kg} / \mathrm{ha} /$ year $)$} & \multirow{2}{*}{$\begin{array}{c}\text { SGR } \\
\left(\% \text { day }^{-1}\right)\end{array}$} & \multirow{2}{*}{$\begin{array}{l}\text { Survival } \\
\text { rate }(\%)\end{array}$} & \multirow[t]{2}{*}{ FCR } \\
\hline & & & $\begin{array}{c}\text { Gross } \\
\text { production }\end{array}$ & Net production & & & \\
\hline $\mathbf{1}$ & 671.60 & 55.03 & 2807.06 & 995.31 & 1.39 & 100 & 4.72 \\
\hline 2 & 509.80 & 42.14 & 2557.78 & 755.52 & 0.10 & 100 & 5.26 \\
\hline
\end{tabular}

Table 3. Month-wise (August 2015 to July 2016) physico-chemical parameters of water in the two experimental ponds

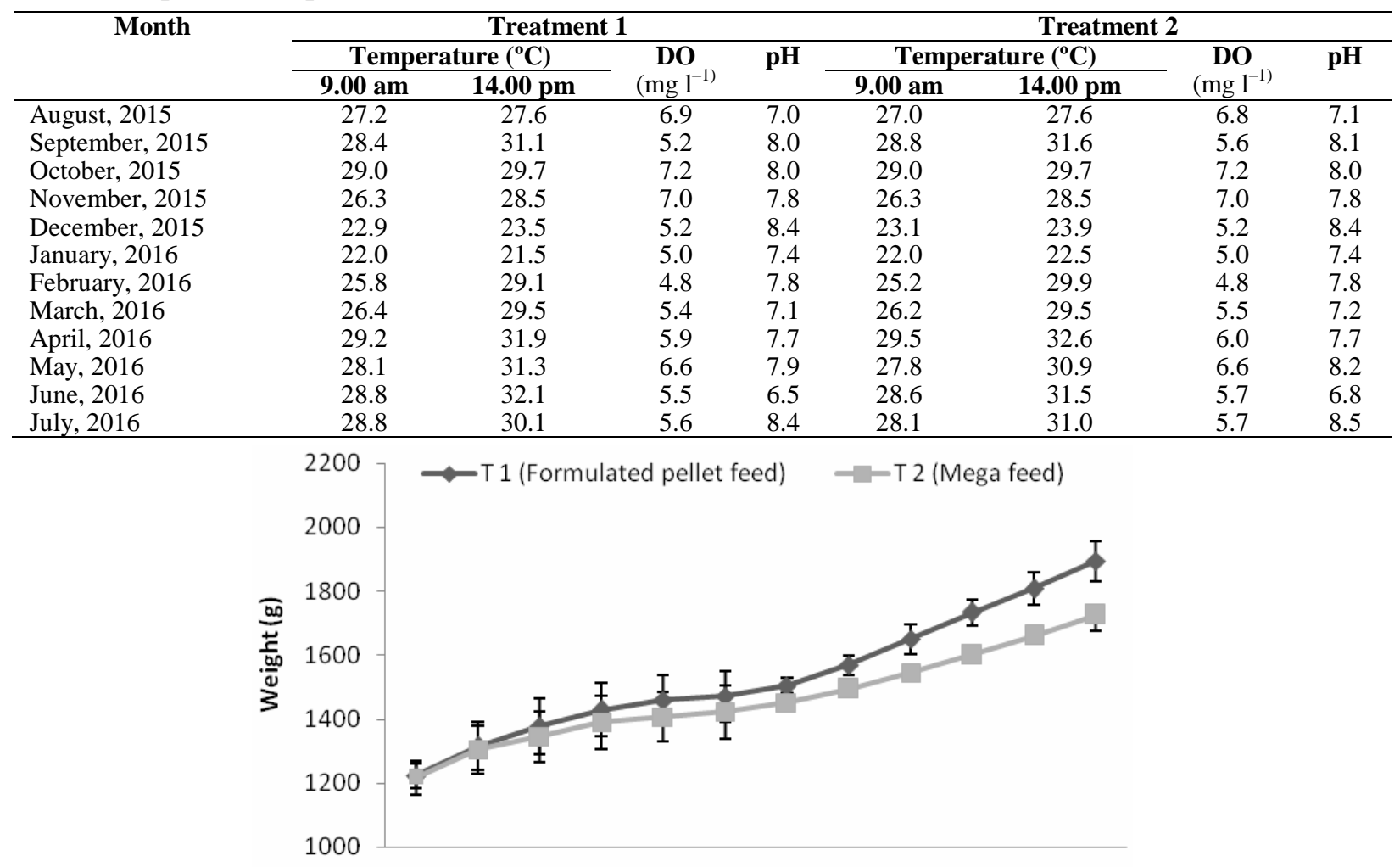

Aug. Sep. Oct. Nov. Dec. Jan. Feb. Mar. Apr. May Jun. Jul.

Month

Fig. 2. Mean increase in weight ( $\mathrm{g}$ ) of $T$. tor during 12 months of rearing with two supplementary feeds 


\section{Discussion}

\section{Growth and Survival}

In the present study, $T$. tor showed impressive growth and mean weight gain as $671.60 \mathrm{~g}$ and $509.80 \mathrm{~g}$ in $\mathrm{T}_{1}$ and $\mathrm{T}_{2}$, respectively. This steady-state growth of fish may be occurred due to the presence of high protein in feed, specially in $T_{1}$. In both feeds, fishmeal was used as the main source of protein. Similar finding was reported by Bista et al. (2002) where T. putitora showed a faster growth from the administration of feed containing high proportion of animal origin ingredients. However, there is no concrete data on the dietary protein requirements of mahseer for pond culture system. In the present study, fish showed better growth with feed containing around $37 \%$ protein which is in agreement with Joshi et al. (1989) who reported $35 \%$ crude protein as the best for growth and feed efficiency of $T$. putitora. Bazaz and Keshavanath (1993) and Misieng et al. (2011) found the optimum dietary protein level for growth of $T$. tambroides fingerlings to be $40 \%$. Sunder et al. (1998) reported better growth, survival and feed conversion with $45.4 \%$ crude protein for $T$. putitora which is similar to the findings of Islam and Tanaka (2004).

In the present study, the SGR $\left(\% \mathrm{day}^{-1}\right)$ of $T$. tor was higher (1.39) in $T_{1}$ than $T_{2}(0.10)$. Higher $S G R$ with commercial pelleted feed containing high protein percentage was also reported by Akram and Swapna (2014), Lone and Lone (2014), Sawhney and Gandotra (2010), Islam and Tanaka (2004), and Islam et al. (2002). Islam and Tanaka (2004) reported SGR of $1.86 \pm 0.14$ using $35 \%$ protein containing feed for putitor mahseer, which is close to the present findings. Misieng et al. (2011) reported low SGR $(0.51 \pm 0.08)$ by using feed containing $40 \%$ protein for $T$. tambroides fingerlings and suggested that SGR improves with increasing dietary protein from $30 \%$ to $50 \%$. Chatta et al. (2015a and 2015b) found SGR of T. macrolepis in polyculture with other carps as $1.59 \pm 0.00$ and $1.09 \pm$ 0.08 with $12.5 \%$ and $25 \%$ protein containing feed respectively, which is similar (1.39) to present findings at $36.67 \%$ protein level. It is evident from the studies that protein percentage does not seem to have any clear relationship with SGR in different species of Tor. It is also difficult to draw any conclusion as the size of stocked fish; feeding frequency and culture duration were also not similar in the reported data regarding this genus.

The FCR values of 4.72 and 5.26 in $T_{1}$ and $T_{2}$, respectively as obtained in the present study were little higher than many of the cultivable species. But these values are almost half of those obtained by Chatta et al. (2015a) on T. macrolepis fed $43 \%$ protein containing feed. They also reported an increasing trend in FCR with increasing ration size from 4-6\% body weight. Sawhney and Gandotra (2010) observed average FCR of $T$. putitora fry as 13.39 at $30 \%$ protein level which is more than double of the present study. In another case, Islam
(2002) obtained FCR of 5.28 for $T$. putitora when sustained with supplementary feed containing $30 \%$ protein under a semi-intensive culture system which is pretty much like to present findings. The possible cause of increased FCR in present research may be the feed digestibility incompetence of fish as De Silva and Davy (1992) suggested that digestibility had an imperative role to lower the value of FCR by efficient food utilization. Low FCR can be achieved by high digestibility, smaller ration size and proper use of feed (Rahman et al. 2006, Misieng et al. 2011). There were also some possibilities of wastage of feed. The digestibility in turn, depends on daily feeding rate, its frequency, and the type of food used (Chiu et al. 1987). The wastage of food might also lead to poor feed utilization and higher FCR. Akram and Swapna (2014) conducted a study on $T$. tor fry by using $25 \%, 35 \%$, and $40 \%$ protein containing pelleted feed and found the FCR as $1.3 \pm 0.02,1.12 \pm 0.03$, and $0.82 \pm$ 0.02 , respectively. These findings differ from the present study which might be due to size variation of fish at stocking.

In both the treatments of the present investigation, the survival rate was found to be $100 \%$ as the fish were larger in size. Hundred percent survival of T. tor in pond was very encouraging and almost similar to the findings of Mohan and Basade (2005), Misieng et al. (2011) and Chatta et al. (2015b) who reported very high survival rates of masheer. Itreflects that this species can equally survive in pond water in Bangladesh. On the contrary, Islam et al. (2002) reported comparatively lower survival (83.8-89.4\%) of $T$. putitora fingerlings in outdoor culture system in Bangladesh.

\section{Water Quality Parameters}

Water temperature is considered as an important factor for fish growth, and according to Aminul (1996), water temperature ranged between 25 to $35{ }^{\circ} \mathrm{C}$ is suitable for fish culture. The water temperature throughout the present experimental period was found within the suitable range. The highest temperature $\left(32.6^{\circ} \mathrm{C}\right)$ was recorded in the month of April due to relatively high intensity of sunlight and absence of cloud in the sky and the lowest $22.0^{\circ} \mathrm{C}$ was recorded in January. The mean temperature varied from $26.05{ }^{\circ} \mathrm{C}$ to $31.05{ }^{\circ} \mathrm{C}$ from February to October and that was varied from $22.25^{\circ} \mathrm{C}$ to $27.4{ }^{\circ} \mathrm{C}$ during November to January in $\mathrm{T}_{1}$ and $\mathrm{T}_{2}$, respectively. The average increment of body weight was recorded as $630.10 \mathrm{~g}$ and $477.0 \mathrm{~g}$ from February to October whereas only $40.50 \mathrm{~g}$ and $32.80 \mathrm{~g}$ increment was recorded during the rearing period of November to January in $\mathrm{T}_{1}$ and $\mathrm{T}_{2}$, respectively. Bista et al. (2002) observed that low water temperatures have been the cause for slow growth of fingerlings of $T$. putitora wherein fingerlings of $19-23 \mathrm{~g}$ attained $44 \mathrm{~g}$ in 6 months. They also suggested that mahseer growth response could be increased with increasing water temperature and this is common with many other cyprinids. In polyculture system of $T$. putitora with Indian major carps, mean weight gained by $T$. putitora was more than $560 \mathrm{~g}$ during 
the culture period of 10 months where mean temperature was $29.4^{\circ} \mathrm{C}$ (Rahman et al. 2005). Ogale (1997) recorded the water temperature between 24 and $28^{\circ} \mathrm{C}$ during monoculture of $T$. putitora in ponds at Lonavla, India with pelletized feed. In another study in the village ponds near Lonavla, India, T. khudree showed an outstanding growth of 600-900 g after 1 year (Basavaraja, 2011). However, stocking density, size of stocked fish and details of feeding in this study were not mentioned. Chatta et al. (2015a and 2015b) found the water temperature to range from $25^{\circ} \mathrm{C}$ to $31.5^{\circ} \mathrm{C}$ in polyculture system with the combination of $T$. macrolepis with L. rohita, C. catla, C. mrigala, $C$. idella, and H. molitrix in Pakistan.

In addition to temperature, fluctuation of DO concentrations might be attributed to alteration in the rate of photosynthesis caused by altering cloudy and sunny weather of the monsoon and also due to variation in the rate of oxygen consumption by fish and other animals through respiration (Boyd, 1982). The dissolved oxygen values during the experimental period were within the productive range in both treatments according to the statement of Jhingran (1991) and Wahab et al. (1995, 1996). In the present study, the values of $\mathrm{pH}$ fluctuated between 7.0 and 8.4, and 7.1 and 8.5 in $\mathrm{T}_{1}$ and $\mathrm{T}_{2}$, respectively which was more or less similar to the $\mathrm{pH}$ values suggested by Hora and Pillay (1962), Swingle (1967), and Rahman et al. (2007).

\section{Conclusion}

This is the first attempt of domestication and evaluation of the culture potential of critically endangered $T$. tor in earthen pond monoculture system in Bangladesh. In wild though it is a slow growing cold water species, growth and survival rate was found very impressive in this experiment. However, trials with large size fish in small pond and treatments without replication have been considered as the main limitations of this experiment. Considering the limitations further research on dietary protein requirement, feeding frequency, and feeding rate of fingerlings or juveniles in large grow-out facility will help in resolving the growth-related issues and artificial breeding of captive reared $T$. tor. This intervention will play a crucial role in helping protection of this critically endangered species and thus restore its populations in the wild.

\section{Acknowledgements}

The authors would like to acknowledge the financial assistance of UGC-World Bank supported HEQEP-AIF to the Sub Project HEQEP CP-3050.

\section{References}

Akram, L. and Swapna, L., 2014. Effect of dietary protein levels on growth, feed utilization, protein retention efficiency of Tor tor (Hamilton, 1822). Journal of Aquaculture Feed Science and Nutrition, 6(1): 1-5.

Aminul, I. M., 1996. Qualities of water and soil in aquaculture. Fish Week Compilation, 1996, DoF publication, Ramna, Dhaka1000, Bangladesh.
Basavaraja, N., 2011. The Deccan mahseer - biology, breeding and conservation. Seminar on Aquaculture and Mahseer Biodiversity Conservation at CIFE, Mumbai. PMCid:PMC3391906

Bazaz, M. M. and Keshavanath, P., 1993. Effect of feeding different levels of sardine oil on growth, muscle composition and digestive enzyme activities of mahseer, Tor khudree. Aquaculture, 115: 111-119. https://doi.org/10.1016/0044-8486(93)90362-3

Bista, J. D., Pradhan, B. R., Shrestha, R. K. and Gurung, T. B., 2002. Nutrition, feed and feeding of golden mahseer (Tor putitora) for domestication and production in Nepal. FAO Fisheries Technical Paper, 431: 107-117.

Boyd, C. E. 1982. Water quality management for pond fish culture. Elsevier Science Publishing Company Amsterdam- OxfordNew York.

Brown, M. E. 1957. Experimental studies on growth. In M. E. Brown (eds). The Physiology of Fishes, vol. I. pp. 361- 400. Academic Press, New York. https://doi.org/10.1016/B978-1-4832-2817-4.50015-9

Chatta, A. M., Ahmad, Z., Hayat, S. and Naqvi, S.A., 2015c. Studies on indoor culture of indus golden Mahseer (Tor macrolepis) in Central Punjab, Pakistan. Pakistan Journal of Nutrition, 14(4): 229-233. https://doi.org/10.3923/pjn.2015.229.233

Chatt, A. M., Ahmad, Z., Hayat, S., Naqvi, S.A. and Khan, A. M., 2015b. Studies on survival of endangered indus golden mahseer (Tor macrolepis) and its impact on growth of other carps. The Journal of Animal and Plant Science, 25(3): $542-549$.

Chatta, A. M., Khan, A. M., Khan, M. N. and Ayub, M., 2015a. A study on growth performance and survival of indus golden Mahseer (Tor macrolepis) with Indian major Carps in semiintensive polyculture system. The Journal of Animal and Plant Science, 25(2): 561-566.

Chiu, Y. N., Sumagaysay, Sastrillo, N. S., Sastrillo, and M. G. S., 1987. Effect of feeding frequency and feeding rate on the growth and feed efficiency of Milkfish, Chanos chanos (Forskal) juveniles. Asian Fisheries Science, 1: 27-31.

De Silva, S. S. and Davy, F. B., 1992. Fish nutrition research for semiintensive culture system in Asia. Asian Fisheries Science, 5: $129-144$.

DoF. 2016. Department of Fisheries, National Fish Week 2016 Compendium (In Bengali), DoF, Dhaka, Bangladesh, p. 148.

Haque, M. Z., Mahata, S. C., Ali, M. Z., Hussain, M. G. and Mazid, M. A., 1995. Seed production of Himalayan mahseer, Tor putitora (Ham.) in Bangladesh. Journal of Asiatic Society of Bangladesh, Science, 21: 279-282.

Haque, M. Z., Rahman, M. A. and Hossain, M. M., 1993. Studies on the effect of stocking densities on the growth and survival of Mrigal (Cirrhinus mrigala) fry in rearing ponds. Bangladesh Journal of Zoology, 21: 51-58.

Hora, S. L. and Pillay, T. V. R. 1962. Hand book of fish culture in the Indo-Pacific region, FAO Fish Biology, Technical Paper, 14, p. 904

Ingram, B., Sungan, S., Tinggi, D., Gooley, G. J., Sim, S. Y. and Silva, D. S. S., 2006. Observations on the growth of cage- and pond-reared Tor tambroides and $\mathrm{T}$. douronensis in Sarawak, Malaysia. Mahseer: The biology, culture and conservation. Proceedings of the International Symposium on the Mahseer, 29-30 March 2006, Kuala Lumpur, Malaysia. Malaysian Fisheries Society, 14: 145-159.

Ingram, B. A., Sungan, S., Gooley, G., Sim, S. Y., Tinggi, D. and De Silva, S. S., 2005. Induced spawning, larval development and rearing of two indigenous Malaysian mahseer, Tor tembroides and T. douronensis. Aquaculture Research, 136: 1001-1014.

Islam, M. S., 2002. Evaluation of supplementary feeds for semiintensive pond culture of Masheer, Tor putitora (Hamilton). Aquaculture, 212: 263-276. https://doi.org/10.1016/S0044-8486(02)00194-1

Islam, M. S. and Tanaka, M., 2004. Optimization of dietary protein requirement for pond-reared mahseer Tor putitora 
Hamilton (Cypriniformes: Cyprinidae). Aquaculture Research, 35: 1270-1276

https://doi.org/10.1111/j.1365-2109.2004.01149.x

Islam, M. S., Dewan, S., Hussain, M. G., Hossain, M. A. and Mazid, M.A., 2002. Feed utilization and wastage in semi-intensive pond culture of Mahseer Tor putitora (Ham.). Bangladesh Journal of Fisheries Research, 6: 1-9.

IUCN Bangladesh (2015) Red List of Bangladesh: A Brief on Assessment Result 2015. IUCN, International Union for Conservation of Nature, Bangladesh Country Office, Dhaka, Bangladesh.

Jhingran, V. G. 1991. Fish and Fisheries of India, 3rd Edn. Hindustan Publishing Corporation, Delhi, India, p. 727.

Joshi, C. B., Sehgal, K. L. and Malkani, K. C., 1989. Experimental trials on feeding of Tor putitora with formulated diets at Bhimtal in Kumaon Himalayas. Indian Journal of Animal Science, 59: 206-209.

Lone, A. H. and Lone, A. K., 2014. Dietary protein inclusion to assess growth and feed utilization in Tor tor (Hamilton, 1822). Agricultural Technology and Biological Science, 11(1): $33-40$.

Mallik, S. K., Sarma, D., Sarma, D. and Shahi, N., 2015. Acid mine drainage, a potential threat to fish fauna of Simsung River, Meghalaya. Current Science, 109: 687-690.

Misieng, J. D., Kamarudin, M. S. and Musa, M., 2011. Optimum dietary protein requirement of Malaysian Mahseer, (Tor tambroides) fingerlings. Pakistan Journal of Biological Science, 14: 232-235. https://doi.org/10.3923/pjbs.2011.232.235 PMid:21870647

Mohan, M. and Basade, Y., 2005. Effect of available diets with different protein to energy ratios on growth, nutrition utilization and body composition of juvenile Himalayan golden Mahseer, Tor putitora (Hamilton). Asian Fisheries Science, 18: 275-283.

Ng, C. K. 2004. King of the Rivers: Mahseer in Malaysia and the Region. Inter Sea Fishery (M) SDN. BHD., Kuala Lumpur, Malaysia.

Ng, W-K., Norfauziah, A., and De Silva, S. S., 2008. The dietary protein requirement of the Malaysian mahseer, Tor tambroides (Bleeker), and the lack of protein-sparing action by dietary lipid. Aquaculture, 284: 201-206. https://doi.org/10.1016/j.aquaculture.2008.07.051

Ogale, S. N. 1997. Induced spawning and hatching of golden mahseer Tor putitora (Hamilton) at Lonavla, Pune District (Maharashtra) in Western Ghats. Fishing Chimes, June 1997: 27-29.
Ogale, S. N. 2002. Mahseer breeding and conservation and possibilities of commercial culture. The Indian Experience. In T. Petr and D. B. Swar (eds). Tata Power Company, Lonavla, pp. 193-212.

Rahman, A. K. A. 1989. Freshwater fishes of Bangladesh. The Zoological Society of Bangladesh, Department of Zoology, University of Dhaka, Dhaka.

Rahman, M. A., Mazid, M. A., Rahman, M. R., Khan, M. N., Hossain, M. A. and Hussain, M. G., 2005. Effect of stocking density on survival and growth of critically endangered mahseer, Tor putitora (Hamilton) in nursery ponds. Aquaculture, 249: 275-284. https://doi.org/10.1016/j.aquaculture.2005.04.040

Rahman, M. A., Rahman, M. R. and Rahman, M. S., 2007. Evaluation of growth and production of the Mahseer, Tor putitora (Ham.) in polyculture with indigenous major carps. Mahseer: The Biology, culture and conservation. Proceedings International Symposium on the "Mahseer 2006", Kuala Lumpur, Malaysia. pp. 161-175.

Rahman, M. M, Verdegem, M. C. J., Nagelkerke, L. A. J., Wahab, M. A., Milstein, A. and Verreth, J.A.J., 2006. Growth, production and food preference of Rohu Labeo rohita $(\mathrm{H}$.) in monoculture and polyculture with common Carp Cyprinus carpio (L.) under fed and non-fed ponds. Aquaculture, 257: 359-372.

https://doi.org/10.1016/j.aquaculture.2006.03.020

Sawhney, S. and Gandotra, R., 2010. Growth response and feed conversion efficiency of Torputitora (Ham.) fry at varying dietary protein levels. Pakistan Journal of Nutrition, 9 (1): 86-90. https://doi.org/10.3923/pjn.2010.86.90

Sunder, S., Raina, H. S. and Naulia, U., 1998. Preliminary feeding trials on juveniles of golden Mahseer Tor putitora (Ham) at different stocking densities with artificial dry pellet feed. Indian Journal of Animal Science, 68: 410-416.

Swingle, H. S. 1967 Standardization of chemical analysis for waters and pond muds. FAO Fisheries Report, 4(4): 397-421.

Wahab, M. A., Ahmad, M. A., Islam and Rahmatullah, S. M., 1995. Effects of introduction of common carp Cyprinus carpio (L.) on the pond ecology and growth of fish in polyculture. Aquaculture. Research, 26: 619-628. https://doi.org/10.1111/j.1365-2109.1995.tb00953.x

Wahab, M. A., Azim, M. E., Haque, M. M. and Ahmed, Z. F., 1996. Effects of frequency of fertilization on water quality and fish yields. Progressive Agriculture, 7(2): 33-39. 